\title{
Customer Relationship Management as a Tool for Sustainable Competitive Advantage and Exemplar Companies with Worldwide Success
}

\author{
Emel Celep \\ Selcuk University, Faculty of Economics and Administrative Sciences \\ Campus, Selcuklu, Konya \\ email:ecelep@selcuk.edu.tr \\ Muammer Zerenler \\ Selcuk University, Faculty of Economics and Administrative Sciences \\ Campus, Selcuklu, Konya \\ email: zerenler@selcuk.edu.tr \\ Esen Şahin \\ Selcuk University, Faculty of Economics and Administrative Sciences \\ Campus, Selcuklu, Konya \\ email:eboztas@selcuk.edu.tr
}

Doi:10.5901/mjss.2013.v4n10p731

\begin{abstract}
In the recent years, due to the existence of innumerable companies, it has become quite difficult to gain advantage in competitiveness. Considering the fact that differentiated activities, strategies and policies of companies or the company resources can easily be imitated by the rivals and the advantage can be lost; the gained advantage in competitiveness should not be for short term and has to carry the necessary qualities for sustainability (Güleş and Bülbül, 2005). In this way, the companies can have a long term relationship with their customers which will bring customer loyalty and long term profit. In addition to the customer loyalty, there are some other conditions that the companies should meet to be preferred. These can be listed as reducing the costs in the production phase; flexibility in meeting the changing needs and demands of the customers fastly and punctually and putting the quality first. The approach of focusing on the customers to secure advantage in competitiveness, brought the approach of Customer Relationship Management. At this point, collecting information about the customers and using them in order to produce unique products and services has become one of the main conditions of an effective and sustainable supremacy in the competition. In this paper, exemplar companies which gained speed, quality and flexibility in their products and services due to their successful implementation of CRM will be analyzed in detail in order to explain the effect of successful CRM implementations in the protection of long-term advantage in competitiveness.
\end{abstract}

\section{Introduction}

In order to gain advantage in competitiveness, companies not only make changes in their organizations and production and marketing strategies but also try to catch up with the changes occuring outside the company. Differences among the strategies of companies explain why some of them prove successful in high productivity, highly demanded products, competitiveness and high profitability (Ünaldı, 2002). According to Porter (1996, p.12), in order to say that the strategy of a company is beter than the startegies of the rivals, there should be a vast difference between them.

Companies work in an environment of intensive competition. Being aware of their advantages and possible opportunities and challenges in front of them, they plan and apply different strategies in order to survive. One of the most important strategies is CRM. CRM is defined as looking at the customer-company relationship from a wide perspective, starting from the planning of the production costs, the production process and a multidimensional and careful analysis of the customer behaviour in order to make deductions for the future (Elden, 2005,p.84). There are many factors behind the emergence of CRM. They can be listed as the increasing costs of mass marketing, increasing importance of the customer compared to the market share, rising importance of the concepts such as customer satisfaction and customer loyalty, appreciation of the importance of existing customers, rising need for keeping the existing customers, necessity of 
developing strategies dealing with each customer singly, intensive competition, developments in the communication technologies and database management systems (Duran, 2002).

\section{Competition, Competitive Advantage and the Sustainability of Competitive Advantage}

Competitive advantage, is the sum of definite differences among companies which gives some a superiority over the others. These superiorities can appear as organizational capabilities. In this context, companies may suceed in some cases in which the others are unsuccessful, make an activity beter than the others or can be the best among the rivals. Besides, competitive advantage may be a result of organizational assets or resources. In this case, company's gaining of the resources it didn't have before, can bring the competitive advantage (Robbins vd., 1999, p.254).

Development, innovation and change are the basic factors for competitive advantage. The main option for a company to secure advantage over the rival international companies is finding a brand-new way of competition or finding brand-new tools in the existing competition environment. For example, Sony was the first company to equip a radio with a transistor. Boeing, one of the leading enterprises in the aircraft industry, offered the idea of a family of planes. With this innovative concept of planes carrying similarities in design, Boeing became the first company to compete globally in its sector. History of all of the global leaders is written by such innovation and success stories (Porter, 1998, p.1). In order to gain compatitive advantage, a company has to make achievements in some activities. These are exceeding the achievements of the rivals, making activities which can not be easily imitated by the rivals and which create customer value, manufacturing products which are hard to substitute and which will cover the average costs (Black et al., 2000, p.213 from Barney 1991).

Sustainable supremacy of competition resembles a long-term success which provides advantage in the competition and the development of superior resources which will become out-of-date until the rivals can imitate them. It is important that in order to block the rivals' opportunity of reaching the same performance, the company should renew its resources to gain temporary advantages, as a challenge in front of the rivals (Black et al, 2000, p.216). A sustainable supremacy in competition exists when a company collects the gains of its investments more than the rivals with similar investments and when the increase in the gains lasts so long that the rivals would not catch up with. It is generally accepted that sustainability depends on three main factors, namely; resistance, transparency \& repeatabality (Finlay, 2000, p.382).

It should not be forgotten that, before starting the strategic implementations for sustainability in competitive advantage, rivals should be analyzed carefully. Competition analysis has four stages: Formulation of a proper strategy in case of competition, finding a superior strategy which would provide advantage in competition, being prepared for the expected reactions of the rivals, finding ways of formulating reactions against the attacks of the rivals (Hussey, 2000, pp.74-75).

\section{Customer Relationship Management as a Tool for Sustainable Competitive Advantage}

In today's world, it has become difficult to find customers by using traditional marketing methods and increasing the profit in this way. What the companies has to do is to prevent the threat of the possible leaving of the existing customers, keeping the existing customers, selling more to them and trying to attract new customers only after this stage. In order to achieve all these, a customer centered organizational structure is needed (Tuğrul, 2006, p.24). CRM is a new concept in relation based marketing and the underlying idea is "treating different customers differently". Main mechanism of the one-to-one marketing strategy comprises understanding the differences among the customers and building a strategy which would enable the company to treat each customer properly (Kırım, 2005, pp.47-49).

CRM is a data baed application and CRM strategies have four stages. The customer selection stage comprises defining the target group, and defining the segmantation, location and marketing strategies for the target group. In the customer attraction stage, the company tries to find the ways of making effective sales via need analysis, preparing offers for buying and pre-demands, and activities such as sales. In the customer keeping stage, the company tries to build loyalty among the customers and secure the sustainability of the relationship via organizing the demands and problem solving. In the second phase of customer keeping, the company aims to increase the spendings of the customer by securing the customer loyalty and profitability gained through activities such as need analysis and cross sales campaigns (Berson et al., 1999). The common point of the successful CRM implementations is that all the processes related to the customer are arranged from the perspective of the customers (Bozgeyik, 2005, p.312). CRM is accepted as a process starting with a relationship settled between the company and the customer, including all the pre- 
sales and after sales activities and providing benefit for both sides. The real aims of the CRM implementions are customer satisfaction and customer loyalty (Söztutar, 2010, p.19).

\section{Exemplar Companies Implementing CRM Successfully}

In accordance with the advances in technology it became possible to collect data about the customers by using information technologies in the points where the company is in touch with the customers such as shops, branches, web sites, call centers, ATM machines and sales points where shopping with credit cards is possible. The collected data is used to build databases, applying data mining and designing effective marketing startegies. Thanks to the new technologies, it became possible to build one-to-one relationship with customers when compared with the costs and the time needed for such an activity in the past (Özmen et al., 2004). CRM unites the elements of human, process and technology to maximize the relationship with all customers. CRM provides a seamless coordination among the customer oriented functions (Goldenberg, 2004). Customers both living in Turkey and in other parts of the world have countless options. Companies use the internet in order to follow the customers, to increase their interest in the company and build customer loyalty. In accordance, e-business acitivities enabling the implementation of CRM via web, have increased. In the following part of the paper, I will try to give information about the exemplar companies implementing CRM in different sectors successfully and give some examples from their implementations:

\subsection{Turkcell}

Turkcell puts CRM in the centre of its strategy and uses the 'Jouney with the Customer' program to maximize customer satisfaction. Turkcell has also attracted attention as the only company to use independent audit in this field. That is why Turkcell is regarded as the number one Turkish company in CRM implementation. Telecommunication giant Turkcell uses CRM to understand the differing needs of customers and providing differentiated service in the each point of encounter with the customers (www.capital.com.tr, 2012).

When we have a look at the the position of Turkcell in CRM services it can be said that the company not only uses CRM implemetations targeting its workers and customers but also provide support to the other companies. In 2006, Turkcell Technologies started many projects for its corporate customers through a specially designed CRM program for them and put the Siebel Sales Force Automation implementation in the service of its corporate sales team. Since 2007, corporate customer representatives of Turkcell manage their relations with the customers via Siebel SFA. In 2007 and 2008, in order to serve both individual and corporate customers, thousands of Turkcell call-center workers started to use the Siebel Call Center implemetation in order to get in touch with the customers not only by phone but also using other channels such as e-mail and fax. Customer representatives can reach in detail information about their customers easily at one stop and can provide need-based service depending on these information. Since 2010, Siebel Order Management implementation, including the individual processes, has been put at disposal of the Turkcell Communication Centres. When compared to many unsuccessful examples of CRM implementation, it can be said that Turkcell Technologies has been successfully implementing CRM projects such as Sales Force Automation, Call Centers and Individual Sales Management (www.techno-labs.com, 2012)

\subsection{Siemens}

Effective use of the CRM implementations by Siemens underlines the importance of the need of having a CRM strategy and an IT solution suitable for the related sector and the clientele in order to protect the investments, to gain net profits and to benefit from the potential of relationship with the customers in sales, marketing and services. At the same time, Siemens IT Solutions and Services works as a CRM partner for other organizations by providing them strategic and technological consultancy, revealing their potential gains and helping them to implement successful projects. Thanks to the Siemens IT Solutions and Services, the company uses strategic CRM implementations which enables sustainable improvement in the customer potential, high productivity with the best solutions in CRM implementation, optimization of the work processes due to its expertize in various sectors and the compatibility of its CRM implementation with the existing IT infrastructure of other companies.

Different areas of work in the company are conducted under a common CRM platform. Within the CRM project of Siemens, many implementations from the integration of the costs of operational processes with the accounting to sending information to the service technicians via SMS, take place (www.capital.com.tr, 2012). 
Workers at the call centers of Siemens IT Solutions and Services, give service to the customers in almost every area of the daily life and by the way attract attention to the effect of CRM on the communication with customers. There are some important numbers showing the success of CRM implementations in collecting information. Some of the examples are: Yearly 2.000.000 flight reservations by customers via easily accessed call center operations of different airway companies; management of yearly 120.000 .000 phone calls under the service dealing with unknown phone numbers; management of yearly 2.600 .000 orders by phone from individual and corporate consumers; yearly 3,000,000 interactions with the customers on the issues such as adress updating, demands for credit cards, calling the customers when there is a problem with the payments, confirmation of the work addresses given in credit card applications by using the CTI technology effectively to maximize contact with the customers and increase operational productivity and interactions on laptops in different languages with yearly 1.500 .000 customers (www.siemens.com.tr, 2012).

\subsection{Amazon.com}

Besides being one of the globally leading bookstores, Amazon.com is also one of the most important retailers in the internet, providing a variety of services. In the competition between actual and virtual bookstores, Amazon.com asserts that trust is also as important as the price and offers a solution to its customers who are used to shopping from actual bookstores. The company took the book buying as a process and divided this process into concrete responsibility groups. By focusing on the customers, the company has become one of the most important retailers on the internet (Seybold, P.B., and Marshak, R.T. (2001); Çiçek 2005, p.81). This website enabling book selling from the internet, the customers can make research, find the products they have been looking for and buy them while sitting in their chairs. In order to make the research process easier for the customers, Amazon.com categorized its products and extended their range by including music and video products and games, enabling the customers to reach different products from the same address.

\subsection{Koç Group}

Koç Group plans to build the largest CRM platform in Turkey with the new work model it has developed. Paro is the first brand of Tanı Marketing and Communication Services company, working within the Koç Information Group. Customers using Paro are identified while they are shopping and the collected information is used to present offers specially designed for them. In this system, companies share the information they have collected and this system provides them the chance of knowing more about the customers and presenting them beter products and services (Çiçek (2004); Çiçek, 2005, p.80). Tanı Marketing and Communication Services is a company which uses technological applications enabling to know the customers perfectly. The company has an international web of communication and marketing and safely provides the most innovative products, services and opportunities to the customers. The company aimed to create e-life spaces for the customers, focusing on implementations close to the customer and producing products and services in accordance with the expectations of the customers, via Paro. With the launch of Paro, the company continued its efforts in the same direction and defined this implementation as a system which gathers customers and companies from the wholesale and retail trade sectors and changes their way of shopping. The company worked together with KoçSistem, Beko, Migros and Koçbank in the development of the technological infrastructure of Paro. All the shopping information about the customers in every department including the producers, retailers and banks were collected in a secure technological infrasture for the benefit of the customers. Paro, analyses buying habits using technology and presents sales, promotions and campaigns specially designed according to their lifestyles, to the customers. The customers who wish to benefit from the Paro, sign up for membership via the credit cards or similar cards that they have already been using and Paro membership can be obtained at the sale points where the Paro stands exist (www.telepati.com, 2011)

\subsection{Harley Davidson}

Harley Davidson brand is presented not only as a motorcycle but also as a jacket, as eye-glasses or an after shave cream. In this way, Harley Davidson desires to produce not only products but a lifestyle for its customers (Kotler, P. (2004); Çiçek, 2002, p.21). Customers view Harley-Davidson as more than a motorcycle producer. It is accepted as a lifestyle comprising a distinguished meaning, image and values for thousands of people (Kotler, 2000, p.166). In order to gain customers for different types of products, Harley Davidson puts the customer in the center. Brand management of Harley Davidson operates with these key aims: Understanding the scope of the company/brand and its meaning for the 
customers, transmitting the brand to the consumers and other target groups, managing the brands in accordance with their life cycles and creating brand equality.

\section{Conclusion}

The analyses in this paper reveals that companies implementing CRM benefited in providing integrated marketing communication, using communication effectively inmarketing, in keeping the customers for long term and securing competitive advantage as well known brands.

A customer in need of buying a product or service, is under the pressure of many potential external, internal and marketing related (products, promotion, channel, service, price, etc.) effects. These factors are important for a customer in their choosing a certain company to buy products. That is why a proper marketing search, important information collected about the customers and the competition strategies chosen are effective in tuurning a company into a well known brand.

Customers, who are accepted as the center of the marketing activities, may behave positively or negatively in their buying behaviours towards the presented products and services. In order to have customers who repeatedly buy the products/services of the company, the company has to analyse the decsion making processes and behaviours of customers and produce accordingly.

The importance of CRM for companies lies in the determining role of the attitudes and behaviours of the customers towards the products and services, which define the success of a company. In the recent years, struggling competition conditions and increasing difficulty in gaining competitive power brings the necessity of securing customer satisfaction and loyalty through proactive marketing decisions. As a result of these developments, companies try to present various porducts and services with different sales techniques to their customers in an environment with the possibility of producing many products and services in the same quality and where the number of the rivals increase fastly. Customer Relationship Management is one of the most effective, productive and important of these technologybased implementations.

\section{References}

Barney, 1991. "Firm Resources anad Sustained Competitive Advantage", Journal of Management 17, No.1.

Berson, A., S., S., Thearling, K. 1999, Building Data Mining Applications for CRM.

Black J.S. ve Porter L. W. 2000, Management: Meeting New Chalenges, Prentice Hall, Inc., New Jersey.

Bozgeyik A., 2005, Rekabet avantajı için Müşteri llişkileri Yönetimi = Başarı, Hayat Yayıncılık.

Çiçek, E. 2005, Süpermarket ve Hipermarketlerde Müşteri Ilişkileri Yönetimi ve Bir Uygulama, Selçuk Üniversitesi Sosyal Bilimler Enstitüsü Doktora Tezi, Konya.

Duran, M., 2002, CRM: Çok Konuşulan ama Az Bilinen Bir Kavram, www.danismend.com. 2002.

Finlay, P., 2000, Strategic Management: An Introduction to Business and Corporate Strategy, Pearson Education, New York.

Goldenberg, B., 2004. Building and Implementing a CRM Masterplan, http://www.crminturkey.org/crm/archive/showppt.asp?pptID=23, 2004

Güleş H., K. and Bülbül H. 2004, Yenilikçilik : İşletmeler İçin Stratejik Rekabet Aracı, Nobel Yayın Dağııım, Ankara.

Hussey, D., 2000, Strategy and Planning: A Manager's Guide, John Wiley\& Sons, New York.

Kııım, A., 2005, Yeni Dünya'da Strateji ve Yönetim, Sistem Yayıncılık, İstanbul.

Kotler, P., 2000, Pazarlama Dünyası, Trans. Muallimoğulları N.,(1999), Milenyum McGraw-Hill.

Mucuk, l., 1998, Pazarlama Illkeleri,Türkmen Kitabevi, İstanbul.

Özmen, Ş. and Özmen, U., 2004 "21.Yüzylın Pazarlama Paradigmasında Pazarlamanın Yeni İkizi: Teknoloj", http://suleozmen.marmara.edu.tr/teblig_sunumlar/10paz_ikizi_teknoloji_sule_ozmen.doc, 2004

Porter, M. 1998, Ulusların Rekabetçi Üstünlüğü, (Ed. Mustafa Özel), Küresel Rekabet, İ Yayıncılık, İstanbul.

Porter, M. E., 1996, What is Strategy?, Harvard Business Review'den aktaran Kotler Philip (2003), (Trans. Ayşe Özyağcllar), Kotler ve Pazarlama: Pazar Yaratmak, Pazar Kazanmak ve Pazara Egemen Olmak, Sistem Yayıncılık, İstanbul.

Black J.S. and Porter L. W. 2000, retrieved from Porter, M., 2000, Competitive Advantage.

Robbins, S., P. and Coulter M., 1999, Management, Prentice Hall, Upper Saddle River, New Jersey, s.254.BERG

Söztutar, T., B., 2010, Pazarlamada Müşteri Illişkileri Yönetimi ve Gıda Sektörü Üzerine Bir Uygulama, Yüksek Lisans Tezi, Kadir Has Üniversitesi, Sosyal Bilimler Enstitüsü, İstanbul.

Tuğrul, M., S., 2009, Müşteri Sadakati Sağlamada Bir Pazarlama Illetişimi Aracı Olarak Müşteri Illişkileri Yönetimi ve Algılanışı Üzerine Bir Araşırıma, Yüksek Lisans Tezi, Marmara Üniversitesi, Sosyal Bilimler Enstitüsü, İstanbul.

Uzunoğlu, E., 2005, Müşteri Odaklı Pazarlama Anlayışı Açısından Değer Zinciri Yönetimi ve Değer Zincirinde Iletişimin Yeri ve Önemi, Doktora Tezi, Ege Üniversitesi, Sosyal Bilimler Tezi, İzmir.

Ünaldı, H., 2002, Strateji Nedir, Ne Değildir?, http://www.danismend.com/konular/stratejiyon/STR-STRATEJI\%20NEDIR.htm. 2008) 
(http://www.capital.com.tr. 2012).

(http://www.capital.com.tr. 2012).

(http://www.telepati.com. 2011)

http://www.siemens.com.tr. 2012)

http://www.techno-labs.com2012) 